\title{
THE FUTURE IN THE PAST: \\ ESCHATOLOGICAL VISION IN BRITISH \\ AND AMERICAN PROTESTANT \\ MISSIONARY HISTORY ${ }^{\prime}$
}

Brian Stanley

\begin{abstract}
Summary
This article examines the strategic significance of different eschatological positions in British and North American Protestant missions. By the late nineteenth century the postmillennial expectation of a world transformed through the work of missions was being challenged by premillennial emphases, particularly in the 'faith' missions. Premillennial mission theorists were not, however, necessarily pessimistic nor indifferent to social concerns until after the First World War. Postmillennial mission theory in the twentieth century moved first towards an expectation of religious convergence, and, after 1968, towards a theology of the kingdom being realised independently of Christian evangelism. The article concludes with some suggestions for a missionary eschatology founded on the biblical vision of a new heaven and a new earth.
\end{abstract}

On 30 September 1908 the celebrated Scottish biblical scholar, George Adam Smith, preached a sermon to the autumn session of the Baptist Missionary Society (BMS), held in Bradford. Smith, at that time a Professor of Old Testament in the United Free Church College in Glasgow, came from stock which had close connections with missions. Throughout his childhood his parents lived at the renowned Baptist mission centre of Serampore, north of Calcutta. His

\footnotetext{
1 An earlier version of this article was delivered to the annual conference of the Evangelical Missionary Alliance (now Global Connections), High Leigh, Hertfordshire, 10 November 1999. Research for this article was conducted under the auspices of the Currents in World Christianity Project, co-ordinated by the University of Cambridge and financed by The Pew Charitable Trusts. The opinions expressed are those of the author and do not necessarily reflect the views of The Pew Charitable Trusts.
} 
father, George Smith, had been the editor of two newspapers that owed their origins to the early Baptist missionaries, The Friend of India and The Calcutta Review, and was the biographer of William Carey, Henry Martyn, and Alexander Duff. George Adam Smith chose as the theme of his sermon 'Mohammedanism and Christianity'. His central concern was to address a problem of theodicy - that is, a question of how to reconcile what appears to be happening in the world with what is known of the character and purpose of God as they are revealed in Scripture:

Among the religions which face us in India and elsewhere, it is of course Mohammedanism which furnishes the most serious and doubtful elements in our anticipations of the future...From the very rise of this Monotheism there has been no greater problem to the faith of Christians, no more obdurate indifference to their Gospel, nor any so dangerous rival in the task of converting the polytheist and idolatrous races of the world. ${ }^{2}$

He went on to review what he called the 'awful facts' of the historical triumph of Islam over Christianity in its original heartlands of Asia Minor and North Africa, and then asked the question of how, given Christian belief in God's providential government of the world, one could make sense of such awful historical facts. It was a highly pertinent question, made more pressing by the reality that the advance of Islam was continuing at the expense of both Hinduism and animism. Smith reported that in the decade from 1891 to 1901 Islam had gained some 5 million adherents in India, thus increasing the Muslim population of the sub-continent by nearly 10 per cent. Among what he termed the 'heathen' populations of Africa and elsewhere, Muslim missionaries appeared to hold the decisive advantage over their Christian counterparts in that they possessed a simple creed which was neither cluttered by western theological forms nor commended by personnel from the western world. ${ }^{3}$ The question Smith was wrestling with was ultimately an eschatological one and is just as pertinent for us: 'how do we fit the signal advance of Islam into our understanding of the purposes of God for the world?'

From the genesis of the evangelical Protestant missionary movement in the mid-eighteenth century supporters of Christian missions had drawn from their Bibles the belief that it was the

2 George Adam Smith, Mohammedanism and Christianity: A Sermon Preached on September 30th, 1908, at the Autumn Session of the Baptist Missionary Society, Held in Bradford (London: A.H. Stockwell, n.d.), pp. 9-10.

3 Smith, Mohammedanism and Christianity, pp. 18-19. 
sovereign purpose of God to bring all humanity to the point of submission to the lordship of Jesus Christ. It was the Father's grand design, in the words of Psalm 2:8, that the nations should be given to the messianic king as his possession, that the name of Christ should be honoured to the ends of the earth. What God in his merciful providence had purposed, the church through its missionary endeavours was called to fulfil. That was the central point of William Carey's famous pamphlet, An Enquiry into the Obligations of Christians to Use Means for the Conversion of the Heathens (1792): Christians were obliged to take the gospel to the 'heathen' world precisely because it was God's revealed purpose to extend the kingdom of his Son throughout the world. ${ }^{4}$ Or, as his much quoted (and still more frequently misquoted) slogan from Carey's sermon on Isaiah 54 preached on 30 May 1792 put it: Expect great things [from God]; attempt great things [for God]. ${ }^{5}$

The goal of the Protestant missionary enterprise as understood by its founders was, then, an eschatological one: it was nothing less than the realisation of the biblical vision of a world transformed by being filled with the knowledge of the Lord as the waters cover the sea. The missionary movement was thus predicated on an ideology of religious replacement: Christianity was destined by sovereign divine purpose to supplant all other religious systems. It was this confidence which fuelled the enthusiasm of missionary recruits throughout the nineteenth century and sustained their flagging spirits in the face of what was (until after the First World War) generally rather a discouraging harvest of conversions. Contrary to what many modern critics allege, this approach encouraged, not a narrow pietism concerned only with the salvation of 'souls', but rather a broad mission strategy which sought to refashion both individual human lives and cultures and societies in what was believed to be a Christian image of justice and humanity. Missionaries in this tradition made major contributions to the

\footnotetext{
4 William Carey, An Enquiry into the Obligations of Christians to Use Means for the Conversion of the Heathens (Leicester, 1792), new facsimile edn., ed. E.A. Payne (London: Carey Kingsgate, 1961).

5 It seems probable that the original form of Carey's motto did not include the words 'from God' and 'for God'; see E.A. Payne, 'John Dyer's memoir of William Carey', Baptist Quarterly, 22.6 (April 1968), pp. 326-27, and A.C. Smith, 'The spirit and letter of Carey's catalytic watchword', Baptist Quarterly, 33.5 (Jan. 1990), pp. 226-37. The slogan is frequently inverted, thus destroying its theological basis in a moderate Calvinist understanding of divine sovereignty.
} 
combating of the slave trade, the courageous defence of the interests of indigenous peoples against exploitation by traders and settlers, and the promotion of humanitarian reform such as the abolition of sati (widow-burning) in British India. The breadth of the postmillennial vision of a world transformed by the gospel and rendered increasingly subject to the lordship of Christ was the great strength of the nineteenth-century missionary movement-yet also its fatal weakness. It was all too easy for such confidence to merge with the faith in the onward march of western civilisation nurtured by the philosophies of the European Enlightenment. ${ }^{6}$ Some missionaries (by no means all), but many more supporters of missions, proved unable in practice to distinguish between gospel values and the particular cultural values of Victorian Britain or America. Relatively few were prepared to be as severely critical of their own supposedly Christian societies as they were of the non-Christian societies to which missionaries went.

By the time of George Adam Smith's sermon in 1908, an increasing body of opinion within the churches on both sides of the Atlantic was questioning the appropriateness of global conversion and social transformation as the goal of Christian missions. At this point, however, the questioning voices belonged, not so much to those such as Smith who had espoused the new methods of biblical criticism, but more to their opponents, evangelicals who followed the path blazed by Edward Irving in the 1820s in seeking to distance the church from worldly methods and assumptions. They distrusted the Victorian and Edwardian confidence in 'Christian civilisation' as a surrender of the purity of the gospel to the Enlightenment gods of technological progress and rationality: they were groping their way towards the conclusion we might well wish to adopt ourselves, namely, that giving western civilisation such ultimate worth was a form of idolatry as potentially dishonouring to God as the idolatry missionaries encountered in India or elsewhere. For such minority voices, the goal of the missionary enterprise was a more limited one: to rescue as many individual souls as possible from eternal perdition in the limited time available before the personal return of Christ. Only through his subsequent millennial rule would the biblical vision of a renewed creation and a just social order be realised. The kingdom of God was not to be constructed brick by brick through the missionary endeavours of the church. This alternative premillennial view was

6 See Brian Stanley (ed.), Christian Missions and the Enlightenment (Grand Rapids and London: Eerdmans and Curzon Press, forthcoming, 2001). 
expressed most starkly in 1887 by Graham Wilmot Brooke, a young Keswick enthusiast and soon to become a lay missionary of the Church Missionary Society (CMS) in Nigeria:

I see no hope given in the Bible that wickedness in this world will be subdued by civilization or preaching of the gospel-until the Messiah the Prince come. And to hasten that time is, I believe the function of foreign missions, 'for the gospel must first be preached for a witness, unto all nations and then shall the end come'. I therefore should be inclined to frame any missionary plans with a view to giving the simple gospel message to the greatest number of ignorant heathen in the shortest possible time. $^{7}$

By this date in Britain premillennialism was attracting a growing proportion of evangelical Anglicans and Baptists, and beginning to affect the policies of the CMS and to a lesser extent the BMS. But the primary impact of premillennialism was of course on the so-called 'faith missions' established on the model of Hudson Taylor's China Inland Mission, founded in 1865. Faith mission principles became generally influential only from the mid-1890s, in North America through the Bible school movement and mission theorists such as A.B. Simpson, A.T. Pierson, and Adoniram Judson Gordon, ${ }^{8}$ and in Britain principally through the figures of Henry and Fanny Grattan Guinness and their children. The Guinness family were the spiders at the centre of almost every British faith mission web at the turn of the century, and were responsible for training some 1,400-1, 500 British evangelical missionaries between 1873 and 1914 at the East London Institute for Home and Foreign Missions (Harley College). ${ }^{9}$

The new faith missions placed their primary emphasis on pioneer evangelism, being concerned to preach the gospel of the kingdom to as many people groups as possible in the limited time believed to be available before the Lord's return. They were generally reluctant to invest in major institutional projects of theological or Christian

7 Cited in Andrew Porter, 'Evangelical enthusiasm, missionary motivation and West Africa in the late nineteenth century: the career of G.W. Brooke', Journal of Imperial and Commonwealth History, 6, 1 (Oct. 1977), p. 38.

8 Dana L. Robert, "The crisis of missions": premillennial mission theory and the origins of independent evangelical missions', in Joel Carpenter and Wilbert R. Shenk (eds.), Earthen Vessels: American Evangelicals and Foreign Missions (Grand Rapids: Eerdmans, 1990), pp. 29-46.

9 C.W. Mackintosh, Dr. Harry Guinness: The Life Story of Henry Grattan Guinness M.D., F.R.G.S. (London: Regions Beyond Missionary Union, 1916), p. 12; see also my article on Henry Grattan Guinness in the New Dictionary of National Biography (forthcoming, Oxford University Press, [2004]); on the Guinness family see Michele Guinness, The Guinness Legend (London: Hodder \& Stoughton, 1989). 
education, believing that such commitments would divert resources of finance and personnel from the primary goal of evangelism. In contrast to the older denominational societies, which remained predominantly postmillennial in eschatology, they made the planting of a church a higher priority than the discipling of that church through programmes for the institutional training of pastors and evangelists. At first they tended also to assume that evangelism would be conducted mainly by western missionaries; whereas the older missions saw their theological training institutions as indispensable means towards achieving the long-term goal of establishing churches that were self-propagating. Initially too, this reluctance to do anything other than evangelism also extended to medical work. Some of the faith mission pioneers, adhering to a marked Keswick-style holiness theology, actually believed that reliance on human medicine rather than divine sustenance was unspiritual. For example, the first three pioneers of the South Africa General Mission into Gazaland (on the borders of modern Mozambique and Zimbabwe) in 1897 ventured into this malariaridden country without quinine or other medicines, trusting only to the Lord to provide for their health. One died within two months; the other two became desperately ill with malaria, but changed their theology, took the tablets, and survived!10 Such attitudes did not last long within the faith missions. Doubts about the theological rationale for ministry that was primarily medical were more enduring, and this was not surprising because medical missions became generally accepted even within the denominational societies only from about the 1880s. The faith missions, to an even greater extent than the denominational societies, hesitated before taking the major and immensely costly step of investing in the construction of hospitals, and for longer than the denominational missions expected qualified medical personnel to function as, in effect, medical evangelists. ${ }^{11}$ Premillennialists tended to see medical care as a means towards the end of winning someone for Christ rather than as an expression of the love of Christ and the values of the kingdom of

10 James Gray Kallam, 'A history of the Africa Evangelical Fellowship from its inception' (New York University Ph.D. thesis, 1978), pp. 182-84. For another example see Robert, 'The crisis of missions', in Carpenter and Shenk (eds.), Earthen Vessels, p. 39.

11 Klaus Fiedler, The Story of Faith Missions (Oxford: Lynx/Regnum, 1994), pp. 226-27, is incorrect to imply that faith missions were as committed as denominational missions to educational and medical work. 
God which needed no other justification to be part of the mission of the church.

There were thus some marked differences in missionary strategy between the older denominational missions and the newer faith ones, differences that can be attributed largely to their contrasting eschatological perspectives. In the period up to the 1920 s, however, the differences were not as great as has sometimes been claimed. Two qualifying points in particular need to be made.

First, and contrary to what is often alleged, 12 it is not the case that premillennialism necessarily leads to an indifference to social issues. Perhaps the most celebrated Christian proponent of social reform in nineteenth-century Britain, Lord Shaftesbury, was a convinced premillennialist. Shaftesbury called for state intervention on behalf of such groups as juvenile mine-workers and chimney sweep boys precisely because he did not believe as a premillennialist that the economy could safely be left to free market forces in order to function with humanity and compassion: left to itself, the world did not and could not exhibit the values of God's kingdom. ${ }^{13}$ It is also noteworthy that from 1903 Henry Grattan Guinness's eldest son and successor as director of the missionary training centre at Harley College, Dr Harry Guinness, abandoned his earlier caution to become one of the most outspoken Christian opponents of the rubber atrocities perpetrated by Belgian concessionary companies within the Congo Free State. ${ }^{14}$ Premillennialism did not automatically imply political quietism-it could impel Christians towards agitation against the wickedness of the world.

Second, premillennialism did not necessarily induce pessimism about the likely progress of Christianity itself, in the sense that premillennialists could, and still do, retain a confidence in the proven capacity of the gospel, faithfully proclaimed in the power of the Spirit, to win individuals for Christ. The Presbyterian, A.T. Pierson, one of the most influential shapers of the premillennial missionary

12 E.g. Peter Kuzmic, 'History and eschatology: evangelical views', in Bruce Nicholls (ed.), In Word and Deed: Evangelism and Social Responsibility (Exeter: Paternoster, 1985), pp. 135-63.

13 Boyd Hilton, The Age of Atonement: The Influence of Evangelicalism on Social and Economic Thought 1785-1865 (Oxford: Clarendon, 1988), pp. 1617, 212-13.

14 Mackintosh, Dr Harry Guinness, pp. 67-79; W.R. Louis and Jean Stengers (eds.) E.D. Morel's History of the Congo Reform Movement (Oxford: Clarendon, 1968), pp. 107, 127, 166, 178, 270-71; Ruth M. Slade, EnglishSpeaking Missions in the Congo Free State (1878-1908) (Académie Royale des Sciences Coloniales, 16. 2; Brussels, 1959), passim. 
tradition in North America, continued even after his conversion to a premillennial position in 1879 to believe that divine providence was opening up the world to Christian missions and to summon the church to aim for the evangelisation of the whole world. ${ }^{15}$ In similar fashion, Henry Grattan Guinness was both a premillennialist and a gospel optimist. His book, The Approaching End of the Age, first published in 1878, which went through no fewer than 13 editions by 1897 (and was re-issued posthumously in 1918), saw the opening of new doors of opportunity for missions as one of the hopeful indications that the return of Christ might not be more than thirty or forty years distant. His signs of the 'approaching end of the age' included some features more characteristic of the postmillennial expectation of a world progressively illuminated by gospel valuesfor example, the overthrow of despotism by democracy-but also some decidedly pessimistic indicators, such as the spread of infidelity and 'open ungodliness' in Christendom'. ${ }^{6}$ For theorists such as Pierson and Guinness, it seems, the present age between the two comings of Christ had two features which might appear at least partially contradictory: on the one hand, it would be increasingly marked by the decay and corruption of a compromised Christendom; yet, on the other hand, the age of Christian history was the age in which missionary labours would be blessed, as the end of Matthew's gospel implies, not simply by the presence of the ascended Saviour but also by his power. ${ }^{17}$ In Pierson's case, there is some evidence that in the course of the 1890s he became less confident that the world as a whole would ever be evangelised, though for the sake of wider evangelical unity he kept his doubts largely to himself. ${ }^{18}$ Pierson, like many others in the period before the First World War, saw faith missions and denominational missions as collaborators in a common evangelical enterprise. As for Guinness, we might well smile at the naïveté with which his book attempted to squeeze modern European history into the prophetic framework of

15 Dana L. Robert, 'Arthur Tappan Pierson and forward movements of late nineteenth-century evangelicalism' (Yale University Ph.D. thesis, 1984), pp. 197-200, 215-24.

16 H.G. Guinness, The Approaching End of the Age, revised edn., ed. E.H. Horne (London: Morgan \& Scott, 1918), pp. 348-49.

17 Guinness, The Approaching End of the Age, p. 350. A similar emphasis is discernible in the 'latter rain' movement in early Pentecostalism.

18 Robert, 'Arthur Tappan Pierson', pp. 206-208, 232; Howard Peskett, 'Missions and eschatology', in K.E. Brower and M.W. Elliott (eds.), 'The Reader Must Understand': Eschatology in Bible and Theology (Leicester: Apollos, 1997), p. 312. 
the book of Revelation: he believed he could see the Reformation in chapter 10, and the French Revolution, the definition of papal infallibility at the First Vatican Council, and a good deal more besides, in chapters 11 and 15.19 But once we have jettisoned the date-crunching of his 'historicist' approach to biblical eschatology, we may feel that his balance between optimism about the progress of the gospel and a degree of scepticism about the ability of the institutional church to hold fast to the gospel may not be that wide of the mark.

Despite real differences of emphasis between postmillennialists and premillennialists, therefore, most Protestant missions in the period before 1918 continued to adhere to the vision of a world substantially won for Christ through the evangelistic agency of Christian missions. This was the period in which literally thousands of evangelical students from British and North American universities volunteered for missionary service under the auspices of the Student Volunteer Movement, and inspired by Pierson's watchword, to which both postmillennialists and premillennialists were able to subscribe, though with contrasting emphases, of 'the evangelization of the world in this generation'. ${ }^{20}$ It was also the period of the great World Missionary Conference at Edinburgh in 1910 in which Protestants of all theological complexions united to make plans for more effective co-operation in the task of winning the world for Christ.

However, beneath the surface of the buoyant optimism and frenetic activism displayed by such events as the Edinburgh conference, there were those who were beginning to grapple with the hard questions of how to make theological sense of the fact that competitors to the gospel were spreading at least as rapidly as Christianity itself. The more pessimistic variants of premillennialism were one way in which evangelicals could solve the problem without diluting in any way their conviction of the uniqueness and ultimate triumph of Christ. Premillennial principles of biblical interpretation were less attractive to others within the evangelical camp, such as George Adam Smith, who had accepted the methods, though not all

19 Guinness, The Approaching End of the Age, pp. 366-67.

20 The watchword was formulated by Pierson on the basis of his reading of a sermon by the English Baptist, Dr Joseph Angus, Apostolic Missions: The Gospel for Every Creature: A Sermon Preached before the Baptist Missionary Society, April 26th, 1871 (London: Yates \& Alexander, 1871); see Robert, 'Arthur Tappan Pierson', pp. 191-92. 
the conclusions, of modern biblical criticism. They had to find other ways of coping with the reality that neither the history of the church nor current mission experience presented a picture of unremitting gospel triumph. Hence Smith's 1908 sermon pushed hard and controversially at the boundaries of the evangelical belief in divine providence by suggesting that in certain contexts God may actually have chosen Islam rather than Christianity as his instrument to combat moral corruption and idolatry. But he did not question directly the paradigm of Christian global victory. For Smith, the expansion of Islam was destined to come to an end. Ultimately the moral and spiritual superiority of Christianity would tell, and Smith concluded his sermon with a not wholly convincing identification of current signs that the impenetrable barrier which Islam presented to the gospel was at last beginning to break up. ${ }^{21}$

The extent of theological consensus on the goals of the mission enterprise maintained at Edinburgh in 1910 has never been repeated. The First World War rocked the foundations of the postmillennial confidence that societies permeated by Christian influence were not far from the kingdom of God. If so-called Christian nations could engage in mutual slaughter on the scale that they did, the quest to construct new Christian nations on the western model no longer seemed so compelling. The Student Volunteer Movement never recovered from the blow, and from 1921 the numbers both enrolling as volunteers and leaving for the mission field plummeted. ${ }^{22}$ With atheistic communism sweeping away the old order in Russia in 1917, the world now seemed a much darker place than it had done in 1910. Broadly speaking, evangelical Christians reacted in one of two ways, which we will consider in some detail.

On the one hand, the war decisively impelled mainstream Protestants in a direction that contributed ultimately to the dilution of the global missionary imperative. This was the case even with some who believed in the premillennial return of Christ. One of the most renowned American evangelists of the twentieth century, the Congregationalist George Sherwood Eddy, supplies a telling example. ${ }^{23}$ Converted as a student at Yale University through the

21 Smith, Mohammedanism and Christianity, pp. 19-31.

22 Nathan D. Showalter, The End of a Crusade: The Student Volunteer Movement for Foreign Missions and the Great War (ATLA MS 44; Lanham, Md., and London: Scarecrow, 1998), pp. 112-13.

23 See R.L. Nutt, The Whole Gospel for the Whole World: Sherwood Eddy and the American Protestant Mission (Macon, Ga.: Mercer University Press, 1997); Brian Stanley, 'The legacy of George Sherwood Eddy', forthcoming in the 
ministry of D.L. Moody, Eddy took the pledge of the Student Volunteer Movement and went to India in 1896 in the service of the YMCA. Eddy was originally an optimistic premillennialist in the Pierson or Guinness mould. His early prayer letters from India are signed off with such earnest phrases as 'Till He come', or 'Keep looking for His return'. ${ }^{24}$ But his reallocation by the YMCA in 1916 to work among the allied troops in Britain and France was the beginning of a profound theological re-orientation for Eddy. Wartime experience convinced him-and many other mainstream evangelical Protestants-that overseas missions were futile unless they were accompanied by a determined effort to convert the social and economic order of the western industrial nations that had plunged the world into catastrophic conflict. It also, incidentally and less typically, implanted in him a fascination with death and the afterlife that was to lead him by the late 1930s into dabbling in spiritualism..$^{25}$ Eddy continued for the rest of his long life (he died in 1963) to believe in and indeed practise global evangelism, but his theology became more and more liberal and his emphasis increasingly a social one: after 1918 it appears that he was no longer a premillennialist.

The great majority of those who, like Eddy, responded to the war by stressing the need for the churches to address the corporate sins of western nationalism and industrial capitalism, continued to believe in the foreign missionary enterprise. From the late nineteenth century onwards, the more liberal sections of evangelicalism had increasingly questioned the confrontational stance which earlier missions had taken towards other religions, and begun to advocate instead theologies of fulfilment, in which missionaries were to present Christ as the one who fulfilled the highest religious and ethical aspirations of non-Christian religious teaching. These reformulations of the missionary task, however, re-conceived the method and process of Christian witness rather than its goal. There was no general abandonment of the call to conversion, nor of the expectation of ultimate Christian victory: according to the evolutionary mind-set which most such thinkers shared, 'lower' religious forms were

International Bulletin of Missionary Research.

24 Yale Divinity School Library, Special Collections, Ms Group 32, G.S. Eddy papers.

25 See Sherwood Eddy, You Will Survive after Death (New York: Rinehart \& Co., 1950), published in Britain as You Will Survive Death (Reigate: Omega, 1954). 
destined to give way to Christianity, still regarded as the highest, if no longer the sole expression of religious truth. However, as awareness intensified during the 1920s of the inroads of secularism into the supposedly Christian lands of the west, some at the liberal end of the missionary movement began to question the appropriateness of calling adherents of other religions to conversion to Christianity. This first became apparent in 1932 with the publication in the USA of the report of the Laymen's Inquiry into Foreign Missions. This was a survey of opinion among a sample of American missionaries from seven of the northern denominational mission boards working in India, Burma, Japan, and China. The Inquiry thus took no account of the views of missionaries in Africa or the Near East (traditionally an area of American missionary concentration), nor of those serving with the more conservative mission boards from the southern states or the faith missions. The Inquiry's report occupied seven volumes, but it was the one-volume version, published under the title Re-Thinking Missions, which attracted most critical attention. The one-volume report was dominated by the views of the chairman of the commission, Professor W.E. Hocking, a Congregational philosopher from Harvard. Hocking insisted that the only confrontation which really mattered was that between religion and non-religion. He also reinterpreted the liberal evangelical missionary philosophy of fulfilment by placing the goal of religious development beyond Christianity itself. The future to which missions pointed was no longer the supercession of other religions, 'but to their continued co-existence with Christianity, each stimulating the other in growth toward the ultimate goal, unity in the completest religious truth'. The aim of missions, therefore, must be redefined as to 'seek with people of other lands a true knowledge and love of God, expressing in life and word what we have learned through Jesus Christ, and endeavouring to give effect to his spirit in the life of the world'. ${ }^{26}$

The Hocking report's abandonment of the principle of religious replacement was by no means characteristic even of mainstream American Protestantism in the 1930s. All of the seven denominational boards which had given their backing to the Inquiry expressed some measure of reservation about the theological stance taken by the report. British and continental missions expressed even

26 W.E. Hocking (comp.), Re-Thinking Missions: A Laymen's Inquiry after One Hundred Years (New York: Harper \& Brothers, 1932), pp. 29, 44, 59. 
stronger objections. ${ }^{27}$ Mainstream Protestant ecumenism as represented by the International Missionary Council, and, after 1948, the World Council of Churches, continued until the mid-1960s to adhere in the most part to some form of the postmillennial goal of a world to be won for Christ through conversion. But the pluralist stance taken by the 1932 report was, of course, given a different and still more radical emphasis after the fourth assembly of the World Council of Churches at Uppsala in 1968. Instead of the Hocking report's emphasis on the evolution of all religions towards a higher synthesis, the accent in mainstream Protestant missiology now fell increasingly on the activity of God in the world. From Uppsala on, large sections of ecumenical Protestantism (though emphatically not all of it) have re-defined the goal of Christian mission in terms of the inauguration of God's kingdom of justice, liberation, humanisation, and the renewal of creation. The core of the old postmillennial vision of a world being progressively transformed into the kingdom of God remains intact, but with two crucial and related differences. First, the kingdom is not to be brought in primarily through the missionary efforts of the church, but rather through the essentially autonomous activity of the Spirit in the world, moving it towards the new humanity. The church is called to co-operate with this free activity of the Spirit, but the proclamation of Christ as Lord is not an indispensable part of the process. Konrad Raiser, the current general secretary of the World Council of Churches, has sought to rationalise this re-orientation theologically by commending the emerging paradigm shift away from the 'Christocentric universalism' of the historic missionary movement--which called for all humanity to submit to the lordship of Christ-towards the post-1968 'trinitarian universalism' 'which is open to humankind and to the creation as a whole by the action of the Spirit'.28 Second-and derivatively from the first- the coming of the kingdom no longer

27 W.R. Hutchison, Errand to the World: American Protestant Thought and Foreign Missions (Chicago \& London: University of Chicago Press, 1987), p. 165; Archibald G. Baker, 'Reaction to the Laymen's Report', Journal of Religion, 13 (Oct. 1933), pp. 379-98. For a modern sympathetic treatment of the Laymen's Report, see Werner Ustorf, Mission to Mission? Rethinking the Agenda (Birmingham: Selly Oak Colleges Occasional Paper No 9, c. 1991).

28 Konrad Raiser, Ecumenism in Transition: A Paradigm Shift in the Ecumenical Movement? (Geneva: WCC, 1991), p. 96. For a critique of Raiser's opposition between a Christocentric and trinitarian basis see Lesslie Newbigin, 'Ecumenical amnesia', International Bulletin of Missionary Research, 18 (Jan. 1994), pp. 1-5, with response by Raiser and reply by Newbigin in the same journal, 18 (April 1994), pp. 50-52. 
bears any necessary relationship to the replacement of other religions by Christianity: confession of the lordship of Christ is no longer the crucial sign of the presence of the kingdom.

Now we must turn to the very different route taken by theologically conservative Protestants in the wake of the First World War. As the social gospel became increasingly identified with more liberal theological stances, many evangelicals lost confidence not simply in social reform but even to some extent also in the ability of the gospel to make any appreciable impact on a lost world. F.B. Meyer, the leading Baptist minister and Keswick speaker, had been renowned before the war for his forthright commitment to issues of social justice. After 1917, however, he became preoccupied with promulgating the message of the premillennial return of Christ, and drew back from social involvement. ${ }^{29}$ Meyer exercised considerable influence on the faith missions, particularly through his role as Acting Director and General Secretary of the Regions Beyond Missionary Union. In 1918 the former suffragette, Christabel Pankhurst, picked up a copy of Guinness's The Approaching End of the Age in a second-hand bookshop, was persuaded of the premillennial position, and became a close associate of Meyer. From 1923 a series of books appeared from her pen proclaiming her disillusionment with the movement for women's suffrage and the whole liberal quest for democracy and world peace: there was no hope for the world, she urged, other than the imminent return of Christ to establish his millennial reign. ${ }^{30}$ Though her books were not specifically concerned with missions, it is noteworthy that one of the reasons she advanced for holding the view that the church could not possibly establish the kingdom was the observation-similar to that made by George Adam Smith in 1908-that 'multitudes are not even in the Church at all'. ${ }^{31}$ A century earlier, evangelicals had made the same observation but had treated it as a summons to go out in the power of the Lord and establish the kingdom.

29 Ian M. Randall, 'The social gospel: a case study', in John Wolffe (ed.), Evangelical Faith and Public Zeal: Evangelicals and Society in Britain 17801980 (London: SPCK, 1995), p. 170.

30 Christabel Pankhurst, 'The Lord Cometh': the World Crisis Explained (London: Morgan \& Scott, 1923); Pressing Problems of the Closing Age (London: Morgan \& Scott, 1924); The World's Unrest: Visions of the Dawn (London: Morgan \& Scott, 1926); Seeing the Future (New York: Harper \& Bros., 1929). For Guinness' influence, see W.Y. Fullerton, F.B. Meyer, A Biography (London: Marshall, Morgan, \& Scott, n.d. [1929]), p. 159, and Pankhurst, 'The Lord Cometh', p. 11.

31 Pankhurst, 'The Lord Cometh', pp. 65-66. 
In the new mood that captured conservative evangelicalism in the 1920s, the priority for true Christians was to hold fast the truth against error, especially any error that might compromise the missionary witness of the church. Denominational missions on both sides of the Atlantic came under increasing attack for their willingness to tolerate biblical criticism and theological modernism. From the early 1920 s they steadily lost supporters both to the faith missions and to newly founded more conservative variants of the denominational missions. The latter became numerous in North America, but there were two such formed in the British Isles: the Bible Churchmen's Missionary Society (BCMS; now Crosslinks), formed by disillusioned conservative supporters of the CMS in 1922, and the (very small) Irish Baptist Foreign Mission, established in 1924 by Irish Baptists anxious at theological trends within the English-dominated BMS. The former was predominantly, and the latter exclusively, premillennial in outlook. ${ }^{32}$ The faith missions began to sever their ecumenical links with the denominational agencies, and to decry 'the social gospel' as a betrayal of the evangelistic imperative. The China Inland Mission, for example, which had been fully involved in ecumenical Protestant missionary bodies, progressively withdrew from such involvement after 1915, finally withdrawing from the National Christian Council of China in 1926.33

Although premillennialists moderated their pessimism in the 1930s, under the influence of expectations of a coming pentecostal revival before the end, a premillennial stance continued to imply separation from what was held to be a worldly understanding of mission and from a church that had made its peace with an apostate world. This was most emphatically true of the growing proportion of premillennialists who were 'futurists', believing that the book of Revelation comprised, not (as Grattan Guinness had supposed) a prophetic guide to the history of the church, but rather a preview of the events that would take place after the 'rapture' of the saints-

32 The Basis of Faith of the BCMS included belief in the second coming of Christ, and the first issue of The Bible Churchmen's Missionary Messenger (January 1923), p. 12, contained an explicitly premillennial article by C.H. Titterton on 'The political outlook'. The preamble to the constitution of the Irish Baptist Foreign Mission made reference to 'the approaching end of the age'; see A.B. Reid, 'A history of the Irish Baptist Foreign Mission (19241977)', (Queen's University, Belfast, M.Phil. thesis, 1999), p. 28.

33 Alvyn J. Austin, 'Blessed adversity: Henry W. Frost and the China Inland Mission', in Carpenter and Shenk (eds.), Earthen Vessels, p. 68. 
their removal from the earth to meet Christ in the air. Futurism displaced the church entirely from the stage on which the final drama of world history would be enacted. Such views were in the majority among American evangelicals from the $1880 \mathrm{~s}$, and increasingly influential, though not yet predominant, in Britain. ${ }^{34}$ Although premillennial convictions were not necessarily the sole source of the extraordinary scale of conservative evangelical missionary activity after 1918, they have undoubtedly supplied much of the dynamic for the unchanging insistence on the urgency of world evangelisation that has been characteristic of conservative evangelical missions since 1918. The AD 2000 movement in our own day is a telling example. ${ }^{35}$ Premillennial evangelicals in the twentieth century, no less than their postmillennial forebears in the nineteenth, have been activists, always busy in the work of the gospel. By the 1980s conservative agencies supplied ten out of every eleven career foreign missionaries from North America. ${ }^{36}$ In Britain, where evangelicals continued to exercise a significant and ultimately growing influence on some of the denominational missions, notably the CMS and the BMS, the proportion was rather smaller, though still high. ${ }^{37}$ Not all of these conservative evangelical missionaries, of course, have been premillennialists. Since the Second World War an increasing proportion of them, especially in Britain, can be described as amillennialists. One of the by-products of the increasing commitment of conservative evangelicals in the second half of this century to biblical and theological scholarship has been a growing dissatisfaction with the hermeneutical basis of dispensational forms of premillennialism. Another has been the recovery, especially since the first Lausanne Congress on World Evangelisation in 1974, of a holistic understanding of Christian mission, as they have been compelled to grapple, just as their liberal evangelical predecessors did at the turn of the nineteenth and twentieth centuries, with the

34 David Bebbington, 'The advent hope in British evangelicalism since 1800', Scottish Journal of Religious Studies, 9, 2 (Autumn 1988), pp. 108-109. Bebbington suggests that futurism became dominant among premillennialists in Britain only from the $1950 \mathrm{~s}$.

35 See http://www.ad2000.org [accessed 16.3.2000]; Peskett, 'Missions and eschatology', p. 319.

36 Carpenter and Shenk (eds.), Earthen Vessels, p. xii.

37 In 1995 member bodies of the Evangelical Missionary Alliance (which included the CMS and some other denominational missions) accounted for $65 \%$ of all Protestant missionaries from the United Kingdom, according to the figures given in Peter Brierley and Heather Wraight (eds.), UK Christian Handbook 1996-7 (London: Christian Research, 1997), p. 504. 
concept of the kingdom of God found in the Old Testament prophets and the synoptic gospels. Though still extremely influential in North America, premillennialism no longer wields a virtual monopoly over the conservative evangelical missionary market. Many amillennial evangelicals are now closer in their theological position to the liberal evangelical mainstream of the earlier twentieth century than they are to the 'fundamentalists' of the 1920s whose spiritual descendants they are. In addition, postmillennialism has made something of a come-back through some of the 'new churches' spawned by the charismatic renewal movement, with their emphasis on the restoration of the kingdom through the work of a Spirit-filled church.

The biggest difference between the missionary attitudes of most British evangelicals and their early twentieth-century predecessors is an eschatological one. The old confidence in the ability of the western churches to evangelise the world in one generation has widely evaporated. Undoubtedly that confidence often bordered on arrogance, as its most distinguished contemporary critic, the German father of missiology, Gustav Warneck, warned in 1900: beneath the frenetic insistence that the world could be evangelised in the current generation lay an implicit trust in the energy, cultural resources, and sophisticated business methods of the English-speaking world, rather than in God himself. ${ }^{38}$ By contrast, many evangelicals today are profoundly sceptical of claims that the key to the spiritual destiny of the world is held in western hands (though the AD 2000 movement can sometimes give the impression of making such claims). That particular form of scepticism I for one welcome as a humble and realistic recognition of the spiritual poverty of the western world. But the change over the last century has not all been for the better. Evangelicals in the first decade of the twentieth century, whether of premillennial or postmillennial persuasion, looked at the world through gospel spectacles-they still retained at least the remnants of the emphasis of Carey and Jonathan Edwards before him on the purpose of God that all humanity should be brought to subjection to the rule of Christ. They still believed that history is the story of God working out his purpose of salvation. After two world wars, the holocaust, the end of the western colonial empires, and the triumph of ideologies of religious pluralism, evangelicals do not find it so easy to affirm the reality of divine

38 Ecumenical Missionary Conference New York, 1900, 2 vols. (London: Religious Tract Society / New York: American Tract Society, 1900), I, pp. 289-91. 
purpose in world history. Providence has been privatised: it is still a reality in the personal lives of believers, but no longer a dominant category in their understanding of the world. That particular grand narrative, like so many others in our post-modern cultural climate, has fallen into disrepute. Any sense that the saving mission of God working through his people, the church, constitutes the central integrating thread of world history is noticeable by its absence from the horizons of contemporary evangelical Christians, at least in Britain. In North America, commitment to world mission is undoubtedly still much more of a defining feature of evangelical church life. My impression, however, is that this commitment arises in part from a futurist variant of premillennialism that does not encourage an integrated Christian perspective on the world. The accent in much (thankfully not all) North American evangelical missionary thinking remains essentially that of the conservative response of the 1920s: on mission as an endeavour to salvage as many individuals as possible from a degenerate world; mission is understood as removing the church from the history of the world rather than sending the church into history to reclaim it for God. That is not to my mind an adequate representation of the biblical understanding of mission. I wish to suggest in conclusion that a biblical eschatology of mission requires that we hold together a vision of the renewal of the created order with an insistence on the centrality of the knowledge of God through Christ.

The historic missionary movement was inspired by the vision found in passages such as Isaiah 11:9 and Habakkuk 2:14 of the earth 'full of the knowledge of the Lord as the waters cover the sea'. The universal knowledge of the Lord is in fact the key to the renewal of creation. Hence the picture in Isaiah 2:4 of swords being beaten into ploughshares is not one of international peace and chumminess achieved through mere human effort and good will. The kingdom of God is not to be brought in by the United Nations, nor even by the World Council of Churches acting as if it were the United Nations. Rather the vision is of 'many peoples' united by their desire to worship the God of Israel and their love for his law (Is. 2:3). There will be no beating of swords into ploughshares until the peoples desire together to worship at the mountain of the Lord. There will be no reconciled humanity without true knowledge of God in Christ. The mission of the church - the new Israel-is nothing less than by spreading this true knowledge of God to promote the renewal of all 
creation, the reconciliation of divided humanity, and to hasten the coming of God's kingdom in its fullness.

Old Testament descriptions of the final goal to which God's purpose of salvation is working are, of course, phrased almost entirely in terms of a restored and renewed earth, rather than in terms of a conventional Christian understanding of 'heaven'. In many ways this strongly terrestrial emphasis is carried over into the New Testament. Revelation 21-22 is more about the new earth than the new heaven: the new Jerusalem is located on a renewed earth, though the city proceeds from ('comes down out of', Rev. 21:2 and 10) heaven. Now it is true that chapters 4-20 of Revelation consist in large part of a vision through an open door into heaven. But they are concerned to emphasise the realities of God's rule and the heavenly worship surrounding his person which may be hidden from the view of God's persecuted people as history moves towards its appointed end. Once that end comes, in Revelation 20 with the final triumph over evil, the 'first' heaven which has been in view in the earlier chapters of the book passes away, along with the 'first' earth which has witnessed the suffering of the saints. In their place we are shown a 'new' heaven and a 'new' earth, though in fact the emphasis is all on heaven come down to earth. The final end-time vision of Scripture is thus not of some dematerialised abstract heaven far above the clouds, as distant as possible from this dirty material earth, but rather of a restored and re-created order for the entire cosmos, at last redeemed from the disfiguring chaos of sin, renewed to its full glorious potential by the saving activity of God (Rom. 8:21), and united in ceaseless adoration of the God whose kingdom'heaven'-will have 'come' on earth in its fullness. Jesus' prayer 'Thy will be done on earth as it is in heaven' will then be answered completely, for the new earth will then be as filled with the presence of God and as perfectly subject to his will as 'heaven' is now. The scriptural testimony seems to me to suggest that in this restored created order, there will no longer be any divorce between heaven and earth: heaven will have come down to earth, and God will be all in all.

The messianic prophecy of Isaiah 11, which Christians believe to have found its deepest fulfilment in the person of Jesus, anticipates the coming of one who will be as full as it is possible for any human being to be with the Spirit of God. He himself will be full of the knowledge of the Lord (11:2), and through his messianic rule the earth itself will become full of the knowledge of the Lord (11:9). That 
vision will only be realised in its completeness when he returns to bring human history to its close. To that extent premillennialism is correct. But in biblical eschatology there is always both a tension and a continuity between the 'already' and the 'not yet'. What God will bring to triumphant summation in Christ we are called to proclaim and indeed to incarnate here and now. The kingdom beyond history is one to which the church throughout the ages is called to witness within history, and the witness is not just a matter of words but of visibility in deeds and being - the church in mission is to be the visual aid of God's present rule and coming kingdom. So that extent an amillennial emphasis has much to commend it. And although the church in mission is not promised universal or unbroken success, it is promised enough of a harvest among all peoples to point unmistakably to the fact that the messianic king, Jesus, is indeed to reign from east to west and south to north. So to that extent postmillennialism has a measure of truth. In the end, labels matter little. What matters is that the church should recover what in the postcolonial era it has lost, namely a true confidence in the universality of the gospel. The western missionary movement in the nineteenth century developed a false confidence in its own methods, spiritual zeal and culture. Although no section of the church is immune from the danger of cultural imperialism, the source of a recovery of a true confidence rooted in God himself seems likely to be the church of the 'two-thirds world', which from its position of economic powerlessness can witness so much more effectively to the Lord of history who one day will be acknowledged universally as Lord beyond history. 